\title{
New records of Forcipomyia (Pterobosca) incubans (Diptera: Ceratopogonidae) parasitizing wings of Odonata in Brazil
}

\author{
Rhainer Guillermo-Ferreira ${ }^{1,3}$ \& Diogo Silva Vilela ${ }^{2}$ \\ ${ }^{1}$ Departamento de Biologia, Faculdade de Filosofia, Ciências e Letras de Ribeirão Preto, \\ Universidade de São Paulo - USP, CEP 14040-901, Ribeirão Preto, SP, Brazil \\ ${ }^{2}$ Laboratório de Ecologia Comportamental e de Interações - LECI, Instituto de Biologia, \\ Universidade Federal de Uberlândia - UFU, CP 593, CEP 38400-902, Uberlândia, MG, Brazil \\ ${ }^{3}$ Corresponding author: Rhainer Guillermo-Ferreira, e-mail: rhainerguillermo@yahoo.com.br
}

GUILLERMO-FERREIRA, R. \& VILELA, D.S. New records of Forcipomyia (Pterobosca) incubans (Diptera: Ceratopogonidae) parasitizing wings of Odonata in Brazil. Biota Neotrop. 13(1): http://www.biotaneotropica. org.br/v13n1/en/abstract?short-communication+bn01013012013

Abstract: Forcipomyia (Pterobosca) incubans Macfie (1937) (Diptera: Ceratopogonidae) is recorded here for the first time for Brazil. Females were collected in the Brazilian Neotropical Savanna parasitizing the wings of Erythrodiplax juliana Ris (1911), Erythrodiplax aff. anomala Brauer (1865) and Erythemis credula Hagen (1861), all Libellulidae dragonflies. A map of potential distribution of this species in the New World is also provided. The results suggest that its distribution may range from southern South America to Mexico, with higher densities in the Brazilian and Colombian Tropical Rain Forests.

Keywords: biting midge, flies, parasite, new record, Neotropical.

GUILlERMO-FERREIRA, R. \& VILELA, D.S. Novos registros de Forcipomyia (Pterobosca) incubans (Diptera: Ceratopogonidae) parasitando asas de Odonata no Brasil. Biota Neotrop. 13(1): http://www. biotaneotropica.org.br/v13n1/pt/abstract?short-communication+bn01013012013

Resumo: Forcipomyia (Pterobosca) incubans Macfie (1937) (Diptera: Ceratopogonidae) é registrada aqui pela primeira vez para o Brasil. Fêmeas foram coletadas parasitando as asas de Erythrodiplax juliana Ris (1911), Erythrodiplax aff. anomala Brauer (1865) e Erythemis credula Hagen (1861), todas libélulas da família Libellulidae. Um mapa da distribuição potencial desta espécie no Novo Mundo também é fornecido. Os resultados sugerem que sua distribuição pode variar do sul da América do Sul ao México, com maiores densidades nas Florestas Tropicais Úmidas do Brasil e da Colômbia.

Palavras-chave: maruim, mosquitos, parasita, novo registro, Neotropical. 


\section{Introduction}

The genus Forcipomyia Meigen (1818) is one of the most diverse groups in the family Ceratopogonidae, with a widespread distribution in the New World and Old World tropics. Some species are known as pollinators of tropical crops, such as cacao (Wirth 1982).

The subgenus Pterobosca Macfie has 23 species distributed worldwide, with only $F$. (P.) fusicornis recorded for Brazil (Borkent 2012). Female ceratopogonids (biting midges) of this subgenus parasite wings of dragonflies and damselflies (Odonata), feeding on the hemolymph of their host (Clastrier \& Legrand 1991, Wildermuth $\&$ Martens 2007). The behavior of these midges may affect the reproductive success of the dragonfly hosts, influencing on their quality and territorial behavior (Orr \& Cranston 1997).

$F$. (P.) incubans Macfie (1937) was described by Macfie (1937) after it was collected attached to the wings of Argia ulmeca Calvert (Odonata: Coenagrionidae) in Belize. Since then, this species was recorded parasitizing 18 Odonata species in South and Central Americas (Huerta 2006); of which 12 occur in Brazil: Hetaerina occisa Hagen in Selys (Calopterygidae), Coryphaeshna viriditas Calvert (Aeshnidae), Erythemis vesiculosa (Fab.) (Libellulidae), Erythrodiplax umbrata (L.) (Libellulidae), Libellula herculea Karsch (Libellulidae), Misagria parana Kirby (Libellulidae), Orthemis schmidti Buchholz (Libellulidae), O. sibylla Ris (Libellulidae) (synonymized with Orthemis ambirufa Calvert, 1909), Uracis imbuta (Burmeister) (Libellulidae), Erythrodiplax melanorubra Borror (Libellulidae), Miathyria marcella (Selys in Sagra) (Libellulidae) and Dythemis sterilis Hagen (Libellulidae).

In this study, we recorded individuals of $F$. (P.) incubans attached to the wing veins of three dragonfly species in the Neotropical Savanna environment of Minas Gerais State, Brazil. We also predicted potential suitable habitat for $F$. $(P$.) incubans, based on maximum entropy distribution modeling considering that such approach may assist future studies and improve the knowledge on the distribution of this group of ceratopogonids.

\section{Materials and Methods}

The study was conducted in the Ecological Reserve of the "Clube Caça e Pesca Itororó de Uberlândia”, Uberlândia, Minas Gerais (18 $57^{\prime} \mathrm{S}$ and $48^{\circ} 12^{\prime}$ 'W; altitude $863 \mathrm{~m}$; $640 \mathrm{ha}$ ). The reserve is covered by a Cerrado stricto sensu (tropical woodland savanna) vegetation and is located near the urban area. The study was conducted in a $\sim 100 \mathrm{~m}^{2}$ pond and an outflow stream, both located inside the reserve.

We collected dragonflies and damselflies with an insect net weekly from 10:00 AM to 3:00 PM between July 2010 and June 2011. After capture, we examined their wings for the presence of parasite midges. When a midge was located, we placed the odonate and the attached parasite in a plastic vial. Manipulation of the dragonfly did not provoke detachment of the midge.

The potential distribution of $F$. (P.) incubans was modeled using the programs Maxent ${ }^{\circledR}$ and Diva-Gis ${ }^{\circledR}$. We used Maxent because it has a strong performance and stability in prediction accuracy, with low sensitivity to sample size (Hernandez et al. 2006, Wisz et al. 2008). Diva-Gis was used to edit the species distribution map gradient, an option that is not included in Maxent. We obtained six georeferenced records of $F$. ( $P$.) incubans (Huerta 2006, Marino \& von Ellenrieder 1999, Clastrier \& Legrand 1990, Macfie 1937, Wirth 1956, Johannsen 1951) and inserted the data in Maxent along with the World Clim's Environmental layers with 2.5 arc-minutes resolution (http://www. worldclim.org/). We used all temperature, precipitation, Bioclim and altitude layers. After running the analysis, we opened the resultant data in Diva-Gis.
Using the file properties and the $10 \%$ percentile training presence threshold (0.249), we created a gradual scale to show the potential distribution of the species. The predictive ability of the generated model was assessed by the Area Under Curve (AUC) of the Receiver Operating Characteristic (ROC) curve (Philips et al. 2006). We adopted the interpretation of AUC results by Araujo et al. (2005): Excellent AUC $>0.90$; Good 0.80>AUC $\leq 0.90$; Acceptable 0.70 $>$ AUC $\leq 0.80$; Bad $0.60>A U C \leq 0.70$; Invalid $0.50>A U C \leq 0.60$. The percent contribution and permutation importance of environmental variables were used to identify what variables contributed more to the Maxent model.

\section{Results and Discussion}

We collected a total number of 605 dragonflies and damselflies, distributed in 17 species, seven Zygoptera and ten Anisoptera. The most common species were Erythrodiplax aff. anomala Brauer, Erythrodiplax umbrata (L.), Zenithoptera lanei Santos, Acanthagrion truncatum Selys, Acanthagrion lancea Selys and Mnesarete pudica (Hagen in Selys).

Only three Libellulidae species had midges attached to their wings: one male Erythrodiplax juliana Ris (12\% of the captured specimens of this species), a Neotropical species (Muzón \& Garre 2005) that oviposits on lentic environments (Carvalho 1998); four males Erythrodiplax aff. anomala Brauer (2\% of the captured specimens of this species); and one male Erythemis credula Hagen ( $5 \%$ of the captured specimens of this species), which is widely distributed in Central and South Americas, dwelling in streams in Argentina (Muzón et al. 2008) and lakes in Brazil (Franco \& Takeda 2002) and Panama (May 1998). This information suggest that this midge may parasitize both stream and lake dwelling odonates, being transported in phoresy to many environments and supporting its wide distribution range. We found only one midge on the basal or apical portion of wings of each dragonfly. Midges clearly had mouthparts

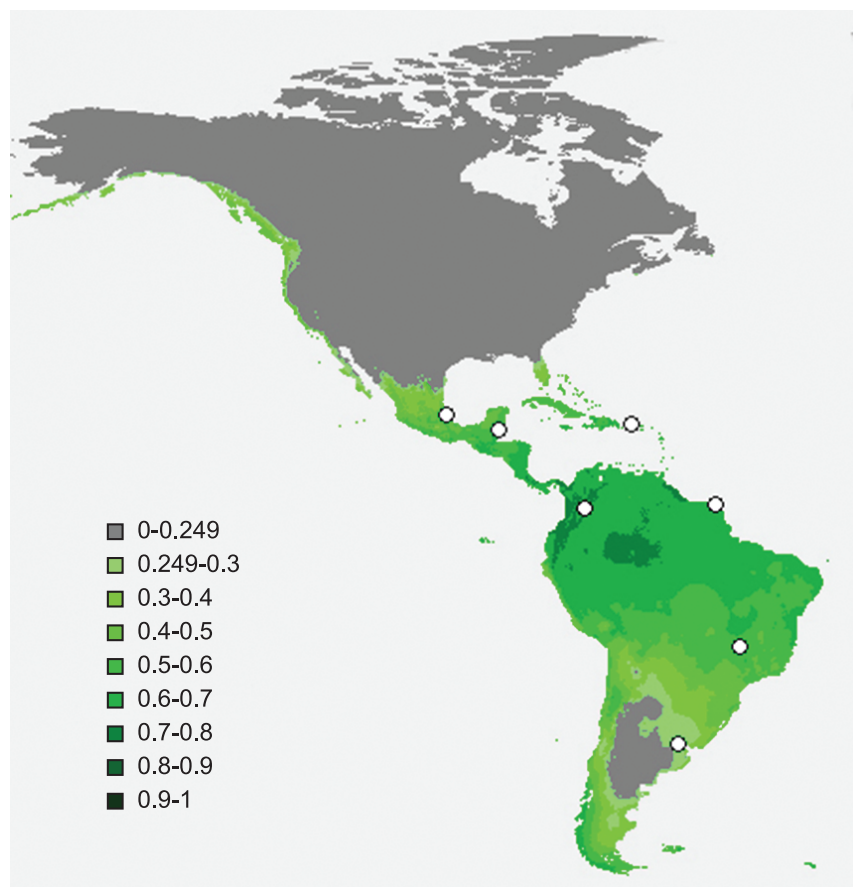

Figure 1. Map of the potential distribution of Forcipomyia $(P$.) incubans (Diptera: Ceratopogonidae) in the New World. Darker tones of green indicate higher probabilities of occurrence. Grey areas indicate low probabilities of occurrence. White circles are sites of observed occurrence. 
inserted in the veins and, after removal, left a scar-like mark on the vein. We collected only male odonates because we could not identify some females that belonged to the same genera.

The results of the potential distribution model for $F$. (P.) incubans (Figure 1) suggest that this species may occur from southern South America to Mexico, with higher probabilities of occurrence in the Tropical Rain Forests of Brazil and Colombia. The model has a good predictability, with $\mathrm{AUC}=0.892$. The results of relative contributions of the environmental variables to the Maxent model show that Temperature Seasonality and Temperature Annual Range (see http://www.worldclim.org/bioclim for descriptions) were the variables with higher percent contribution ( 87.7 and 8.2 , respectively) and permutation importance (57.7 and 41.3 , respectively). The contribution of these predictor variables and the potential high occurrence in tropical forests suggest that this species may present higher occurrence probabilities in habitats where temperature shows little variation throughout the year. Since temperature regimes influence on the odonate host development and distribution (Corbet 1999, Dingemanse \& Kalkman 2008), such variables should also influence on the distribution of the parasite midge.

In conclusion, the results suggest that this midge may be a common parasite of dragonflies, with a wide distribution in the Americas. In addition, since this midge presents no host specificity, it is highly probable that this species can be found parasitizing other Odonata species in other parts of the Americas.

\section{Acknowledgements}

We thank Dr. Kleber Del Claro, Dr. Pitágoras C. Bispo and the direction of the Ecological Reserve for supporting this study. We also thank Dr. Gustavo Spinelli for insect identification. We acknowledge Dr. Fabio de Oliveira Roque and two anonymous referees for their valuable comments, which greatly improved this manuscript. RGF thanks CAPES for financial support.

\section{References}

ARAUJO, M.B., PEARSON, R.G., THUILLER, W. \& ERHARD, M. 2005. Validation of species-climate impact models under climate change. Glob. Change Biol. 11: 1504-1513. http://dx.doi.org/10.1111/j.13652486.2005.01000.x

BORKENT,A. 2012. World species of biting midges (Diptera: Ceratopogonidae). www.inhs.uiuc.edu/research/FLYTREE/CeratopogonidaeCatalog.pdf (último acesso em 06/08/2012).

CARVALHO, A.L. \& NESSIMIAN, J.L. 1998. Odonata do Estado do Rio de Janeiro, Brasil: Hábitats e hábitos das larvas. Oecol. Austral. 5: 3-28.

CLASTRIER, J. \& LEGRAND, J. 1990. Forcipomyia (Pterobosca) incubans (Macfie) et $F$. \{Trichohelea) machen n. sp. Parasites des ailes de libellules en Guyane Française (Diptera, Ceratopogonidae; Odonata). Rev. Fr. Entomol. 12: 167-170.

CLASTRIER, J. \& LEGRAND, J. 1991. Forcipomyia (Trichohelea) araneivora $\mathrm{n}$. sp. ectoparasite d'une araignée habitant les monts nimba en Guinée (Diptera, Ceratopogonidae; Araneae, Araneidae). Rev. Fr. Entomol.13: 155-158.
CORBET, P.S. 1999. Dragonflies: Behavior and Ecology of Odonata. Comstock, Ithaca.

DINGEMANSE, N.J. \& KALKMAN, V.J. 2008. Changing temperature regimes have advanced the phenology of Odonata in the Netherlands. Ecol. Entomol. 33: 394-402. http://dx.doi.org/10.1111/j.13652311.2007.00982.x

FRANCO, G. \& TAKEDA, A. 2002. Variação espacial e temporal de larvas de Odonata associadas com macrófitas aquáticas em duas lagoas da planície de inundação do alto rio Paraná, Brasil. Biol. Sci. 24: 337-344.

HERNANDEZ, P.A., GRAHAM, C.H., MASTER, L.L. \&ALBERT, D.L. 2006. The effect of sample size and species characteristics on performance of different species distribution modeling methods. Ecography 29: 773-785. http://dx.doi.org/10.1111/j.0906-7590.2006.04700.x

HUERTA, H. 2006. Nuevo registro de Forcipomyia (Pterobosca) incubans (Macfie) (Diptera: Ceratopogonidae) como parásito de Odonata. Acta Zool. Mex. 22: 157-158.

JOHANNSEN, O.A. 1951. Notes on North American species of Pterobosca. Fla. Entomol. 34: 116-117. http://dx.doi.org/10.2307/3492023

MACFIE, J.W.S. 1937. Notes on Ceratopogonidae (Diptera). Proc. R. Entomol. Soc. Lond. 6: 111-118.

MARINO, P.I. \& VON ELLENRIEDER, N. 1999. New records of Forcipomyia (Pterobosca) incubans (Macfie) (Diptera: Ceratopogonidae) on libellulids (Anisoptera). Not. Odonatol. 5: 38-39.

MAY, M. 1998. Body temperature regulation in a late-season dragonfly, Sympetrum vicinum (Odonata: libellulidae). Int. J. Odonatol. 1: 1-13. http://dx.doi.org/10.1080/13887890.1998.9748090

MUZÓN, J. \& GARRÉ, A. 2005. Description of the last instar larva of Erythrodiplax paraguayensis (Anisoptera: Libellulidae). Rev. Soc. Entomol. Argent. 64: 85-91.

MUZÓN, J., VON ELLENRIEDER, N., PESSACQ, P., LOZANO, F., GARRÉ, A., LAMBRUSCHINI, J., RAMOS, L. \& MUÑOZ, M.S. 2008. Odonata from Iberá Wetlands (Corrientes, Argentina): preliminary inventory and biodiversity. Rev. Soc. Entomol. Argent. 67: 59-67.

ORR, A.G. \& CRANSTON, P.S. 1997. Hitchhicker or parasite? A ceratopogonid midge and its odonate host. J. Nat. Hist. 31: 1849-1858. http://dx.doi.org/10.1080/00222939700770961

PHILIPS, S.J.,ANDERSON, R.P. \& SCHAPIRE, R.E. 2006. Maximum entropy modeling of species geographic distributions. Ecol. Model. 190: 231-259. http://dx.doi.org/10.1016/j.ecolmodel.2005.03.026

WILDERMUTH, H. \& MARTENS, A. 2007. The feeding action of Forcipomyia paludis (Ceratopogonidae, Diptera), a parasite of Odonata imagines. Int. J. Odonatol. 10: 249-255. http://dx.doi.org/10.1080/1388 7890.2007 .9748302

WIRTH, W.W. 1956. New species and records of biting midges ectoparasitic on insects (Diptera, Heleidae). Ann. Entomol. Soc. Am. 49: 356-364.

WIRTH, W.W. 1982. The cacao-pollinating midges of the Forcipomyia argenteola group (Diptera: Ceratopogonidae). Proc. Entomol. Soc. Wash. 84: 568-585.

WISZ, M.S., HIJMANS, R.J., LI, J., PETERSON, A.T., GRAHAM, C.H. \& GUISAN, A. 2008. Effects of sample size on the performance of species distribution models. Diversity Distrib. 14: 763-773. http://dx.doi. org/10.1111/j.1472-4642.2008.00482.x 